\title{
Morphology of Street Vegetation Along Pedestrian Walkways in Kuala Lumpur City Centre
}

\author{
Hazreena Hussein 1, Nur Ameelia Rokhaza'ain Mohsin ${ }^{2}$ \\ ${ }^{1}$ Centre for Sustainable Urban Planning \& Real Estate, ${ }^{2}$ Department of Architecture, \\ University of Malaya, Kuala Lumpur 50603, Malaysia \\ reenalambina@um.edu.my, ameeliarokhazaain@gmail.com \\ Tel: +60379677674
}

\begin{abstract}
The Kuala Lumpur City Hall (KLCH) has planted 100,000 trees along the main streets of the city centre through the National Economic Transformation Programme to make the city more liveable. This paper studies the reasons for its different establishments, and it determines the social and physical benefits to the pedestrian walkways through a further investigation regarding the morphological parameters used by the Landscape Department of $\mathrm{KLCH}$. The outcomes indicated that the street vegetation morphology implemented is mainly to improve the social and physical condition of the pedestrian walkways, especially the safety of the pedestrians due to snatching and reckless crossings.
\end{abstract}

Keywords: Street Vegetation; City Centre; Main Street; Pedestrian Walkways

eISSN: 2398-4287 @ 2019. The Authors. Published for AMER ABRA CE-Bs by e-International Publishing House, Ltd., UK. This is an open access article under the CC BYNC-ND license (http://creativecommons.org/licenses/by-nc-nd/4.0). Peer-review under responsibility of AMER (Association of Malaysian Environment-Behaviour Researchers), ABRA (Association of Behavioural Researchers on Asians) and cE-Bs (Centre for Environment-Behaviour Studies), Faculty of Architecture, Planning \& Surveying, Universiti Teknologi MARA, Malaysia.

DOI: https://doi.org/10.21834/e-bpj.v4i12.1627

\subsection{Introduction}

Street vegetation has been an integral part of the urban landscape. It was the Italian Renaissance and French Baroque influence that introduced the concept of planting rows and avenues of trees (Chevallerie, 1983). Trees serve the environment like air and water purifier, wind and noise filter, which, are crucial significance for the liveability of modern cities and the well-being of urban residents (Chiesura, 2004). In Malaysia, the earliest urban tree planting, Angsana (Pterocarpus indicus) was planted in 1778 in Malacca (Koening, 1894) and Penang in 1802 (Burkill, 1966).

The first planned greening programme in Malaysia started in Kuala Lumpur in 1973 under the Beautification Programs of Kuala Lumpur (Ayoub, 1989). Greening the city program in Kuala Lumpur was officially instituted in the planning process when the 1973 Act 267 was revised in the Federal Territory (Planning) Act of 1982 (Act 267). It stipulated the rules and regulations for planting, cutting, and conservation of urban trees. Other than the tree planting program, an emphasis on urban tree planting has also included in the Kuala Lumpur Structure Plan (DBKL, 2004). This consists of shade tree plantings, the establishment of themed gardens, ornamental plantings, slope plantings and roadside plantings (Sreetheran, 2011).

With the Kuala Lumpur city centre, rail transports wholly opened in 1999, its central rapid city centre interchange station at Masjid Jamek, the pedestrian network around its immediate context was developed. They are connecting main transport nodes by widening and shading of walkways with a more attractive appearance to provide a pleasant walking experience. The Economic Transformation Program (ETP) in September 2010 initiated to elevate the country to developed-nation status by 2020. As part of the efforts, KLCH aimed to increase greenery in the city by planting 100,000 large-coverage trees within three years from 2011 to 2014 . This study aims to explore the development of the street vegetation of the three year-tree planting projects and review its establishments along with the

eISSN: 2398-4287 C 2019. The Authors. Published for AMER ABRA cE-Bs by e-International Publishing House, Ltd., UK. This is an open access article under the CC BYNC-ND license (http://creativecommons.org/licenses/by-nc-nd/4.0/). Peer-review under responsibility of AMER (Association of Malaysian Environment-Behaviour Researchers), ABRA (Association of Behavioural Researchers on Asians) and cE-Bs (Centre for Environment-Behaviour Studies), Faculty of Architecture, Planning \& Surveying, Universiti Teknologi MARA, Malaysia. DOI: https://doi.org/10.21834/e-bpj.v4i12.1627 
pedestrian network of the main roads in the city centre. The review is only part of determining the process to explore how street vegetation is established within the city hall's morphological parameter and its contribution to safe and pleasant walking experience for pedestrians.

\subsection{Literature Review}

Morphology is defined as the study of forms of things and the shape of a structure. It is the branch of biology that deals with the kind of living organisms, and with relationships between their structures (Oxford, 2012). Morphology of vegetation comprises of structural properties of the plant, mainly in the height, density, species, and functionality along with its composition (Mishra, 2015). Vegetation morphology, on the other hand, is usually developed based on countenance (i.e., structure and density) and species composition. It is often the accurate representation of the typical co-existence of trees, shrubs, and grasses, considering the layering system of vegetation and vegetation properties.

\subsection{Historical background of street trees}

The earliest features of rows of trees along a street date back nearly 500 years from the present day. Tree-lined avenues made its first appearance on the European continent in the Italian Renaissance gardens of the first half of the 16th century. They were then "imported" to France, which had been used for passageways in buildings and now came to designate a pathway in most gardens (Pradines, 2009). During the Renaissance, trees were in private gardens for fruit production and aesthetics. Renaissance villas walled with gardens and trees lined as pathways in the gardens (Miller, 2014).

In the beginning, the rows of trees were only to create a focal point in the gardens, but designers soon had the idea of creating vistas, which led to tree-lined roads. The planting of trees along roadways is to prevent neighbouring landowners trespassing on public territory and vice versa. Trees along the street were also known to shelter travellers from the wind, provide shade in sunny areas and prevent soil erosion caused by wind (Pradines, 2009).

\subsection{Rationale of implementation of urban vegetation along streets}

In the cities, trees provide shade and refresh the environment by evapotranspiration (Dimoudi, 2003). Physically, trees are planted in urban areas to improve the appearance of the streets. Kent (1993) demonstrated the positive effects of naturalistic roadways, where there is a greater appreciation of freeway roadsides with trees. The roadside environment also influences road choice. Research by Smardon (1988) concluded that trees break up continuous building facades and provide delineation of space, shrubs anchor structures to the ground and grass and ground cover help to define pavement edges.

\subsection{Impact of urban vegetation on the streets and pedestrian walkways of cities}

Most city-dwellers spend their time on the streets. Some streets are not at all attractive to pedestrians and drivers, whereas some may be equally appealing to both users. According to Jacobs (1997), roads should be comfortable and appealing with places to walk at a leisurely pace in safety and have something to catch the eyes of both pedestrians and drivers. Included, in the list qualities that roads should consist of vegetation (Antiput, et al., 1996). It has shown that the presence of trees is vital and valuable for the urban environment of a streetscape (Anderson1988).

\subsection{Impact of pedestrian walkways}

The presence of trees encourages people to walk as an exercise and as a mode of transportation (Mitchell, 2007). When trees are planted along the curb, especially when closely spaced, it helps define a pedestrian zone separated from traffic, which creates a sense of safety both physically and psychologically (Foundation, 2003). Safety perception of users is an essential component of walkability. Trees planted in between footpath and roadway reduces the risk of being hit by a 'run-off-the-road' vehicle (Jacobs, 1993). It is critical to include trees and landscaping in the street environment so that people would want to walk in, especially as a mode of transportation in the city centre. Furthermore, Walks (2017) added that benefits for walkers comprise of both practical and aesthetic with street trees providing shelter for the pedestrian walkways.

\subsection{Impact of urban vegetation in the city}

A city must have a strong connecting green asset. The urban plant is a critical contributor to the significant streetscape and excellent walkability. Good streets and walkability are essential for a sustainable city (Zakaria, 2015). A study established by Technology (2012) mentioned that plants growing in the concrete cities can reduce levels of air pollutants by eight times more than previously believed, making a city more liveable and healthy. Therefore, urban vegetation does give a significant impact on the quality of a city as it improves the walkability of the streets, which enhances the residents' quality of living and promotes a more sustainable environment (Shamsuddin, 2012).

\subsection{Methodology}

This study employed several qualitative methods and started with a preliminary review of several streets within the Kuala Lumpur city centre. It first investigated their changes with consideration to the noticeable amount of green planting that was implemented by the city hall. It then moved onto a semi-structured interview with the Head of Landscape Architect of the KLCH to confirm the changes that 
took place and the street vegetation morphology components used along the streets. The study proceeded in collecting the data of the selected street areas that linked to the main street of the Masjid Jamek LRT interchange station, Jalan Tun Perak (Figure 1). Eight main streets found to have this criterion, including Jalan Tun Perak itself. They went through the greening works from the end of the year 2012 until the end of the year 2015.

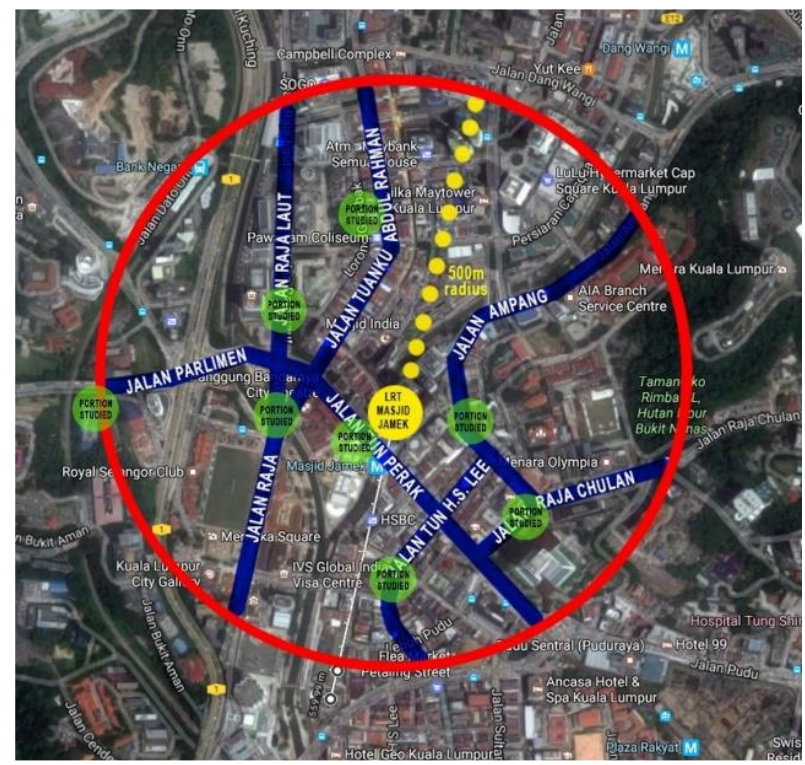

Fig. 1: The location of Masjid Jamek LRT on Jalan Tun Perak and its direct linkages to the remaining studied streets (Source: Author)

The objective of this study is to explore the morphology of street vegetation along the main streets of the city centre and to discover the list of street vegetation design components constructed by the $\mathrm{KLCH}$. The data recorded would then make clear evidence of the present street vegetation works done by the city hall's landscape architects. It discovers the reasons for establishment; street vegetation morphological parameter set by the city hall, its objectives, and relation to the pedestrian walkway. Due to time limitation, this study only covers the main streets that were involved in the ETP and its relationship to the pedestrian walkways.

\subsection{Findings}

\subsection{Street Vegetation Morphology Components}

Based on the components of vegetation morphology studied in the literature review, vegetation morphology is usually developed based on vegetation physiognomy; structure and density (Mishra, 2015). The elements measured are the dimensions of the tree canopy, shrubs, pedestrian walkways, and other structures, which are built together with the street vegetation like streetlamps, fences or seating furniture. The interview done with the landscape architect of the $\mathrm{KLCH}$ will help to understand the effects and rationale of the recorded observation and dimensions through the aspects of i) Street Location, ii) Safety, iii) Comfort and iv) Visual Aesthetics.

\subsubsection{Street Location}

Based on the interview with the Deputy Director of Landscape and Recreational Department of KLCH, Nik Adlin Nik Hussain, there are different parameters set by the city hall for the establishment of the green zone following the Greener KL project set by PEMANDU. To plant 100,000 trees within three years, the street vegetation is planted mainly according to the location of the streets. Nik Adlin mentioned, "The trees are usually chosen based on the site constraints. For example, hardy plants are plants that require low maintenance like watering. Even without regular watering, these plants should be able to grow on their own. The important site, which is nearer to the protocol area like Jalan Raja, where the Merdeka Square is, has more labour supplies since the city hall is given more budgets to cater to the plants. The vegetation planted on such site is also composed of more expensive plants".

Therefore, Jalan Raja Chulan and Jalan Ampang are planted with more hardy plants since they are located further down from Masjid Jamek LRT station. These streets do not carry any protocol requirement as compared to other streets, which have important buildings around them.

\subsubsection{Safety}

Nik Adlin cited that Kuala Lumpur started to plant more trees as a barrier and edging to separate the road and the pedestrian walkway since the Safe City Campaign took place in the year 2010 (Government, 2010). Trees planted along a curb helps define the pedestrian zone separated from the traffic, which creates a sense of safety both physically and psychologically (Foundation, 2003). He added, "We can't compare the reasons for the establishment of street vegetation in Kuala Lumpur and other countries. Here, we plant trees 
and shrubs for very different reasons due to social behaviour and culture. Most developed countries do not have barricade or fencing along the street vegetation. Still, Kuala Lumpur needs it due to many cases of road accidents, snatching and illegal usage of pedestrian roads by motorcyclists".

Trees planted in between footpath and roadway reduces the risk of being hit by a run-off-the-road vehicle (Jacobs, 1993). In Kuala Lumpur, trees and shrubs are planted to prevent vehicles from running a person first. Instead, with this strategy, it is more likely for the cars to hit the green zone first, either tree or the shrubs.

\subsubsection{Comfort}

Being given the trust by the ministry for the Greener KL project, the Landscape and Recreational Department of the City Council of Kuala Lumpur also intended for the vegetation planting to improve the walking environment of the pedestrians in the city centre. It is said to be critical to include trees and landscaping in the street to create an environment that people would want to walk in. The practical benefit is when the trees provide shelter for pedestrian walkways (Walks, 2017). As explained by Nik Adlin, "The areas where trees and shrubs are planted along the pedestrian walkways act as the 'green zone' where this zone intends to enhance the surrounding requirements. They connect the existing pedestrian walkways where walking feels more accessible and more comfortable for the pedestrians to reach one place to another".

Urban vegetation gives a significant impact on the quality of a city. As it improves the walkability of the streets, it creates a liveable place. A liveable place enhances the quality of access and linkages in the town centre and urban areas, and a city becomes liveable when transportation is made sustainable with low noise and air pollution, which will then contribute to a comfortable walk.

\subsubsection{Visual Aesthetics}

Nik Adlin stated, "The green zones are usually in line with all the utilities like the streetlamps for easy reference and also for a clean arrangement for the street. We have also designed the green zone, especially in Jalan Tuanku Abdul Rahman (TAR), with all the design elements of colours, texture, and line which compose a form. All these elements are to add up to the attractive characteristics of Jalan TAR itself. Since it is a place for tourists and local shopping areas, we have given Jalan TAR a specific theme. A colourful, merrier looking landscape".

It was concurred by Smardon (1988) that all forms of vegetation contribute to visual improvement where trees break up continuous facades and provide delineation of space, shrubs anchor structures to the ground and grass and ground cover help to define pavement edges.

\subsection{Drawing Analysis}

\subsubsection{Jalan Tun Perak (Figures 2a;b)}
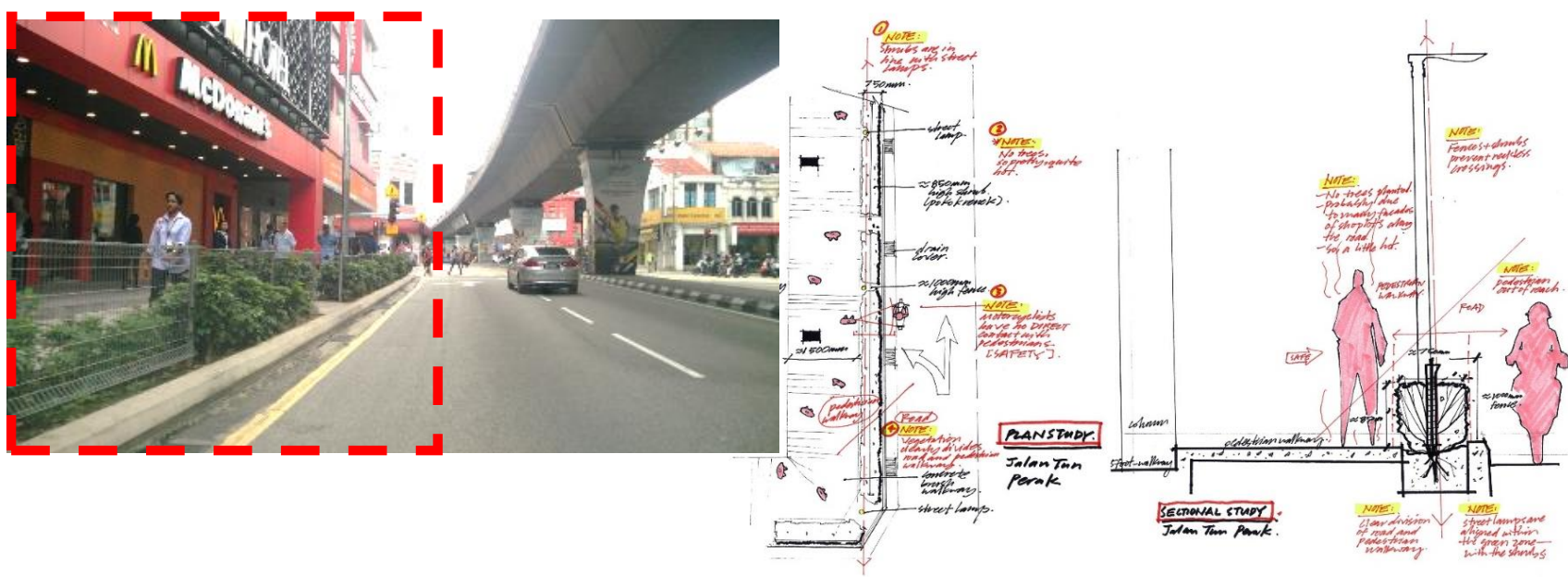

Fig. 2. (a) View of the street vegetation of Jalan Tun Perak; (b) Plan and sectional study drawing of the street vegetation of Jalan Tun Perak (Source: Author)

Table 1. Findings of the street vegetation morphology components of Jalan Tun Perak.

\begin{tabular}{ll}
\hline Street location & Safety \\
\hline $\begin{array}{l}\text { It is located about } 50 \text { meters from the LRT station. } \\
\text { It consists only shrubs. }\end{array}$ & $\begin{array}{l}\text { Figures 2(a) and (b) show a clear division } \\
\text { between the street and pedestrian walkway. } \\
\end{array}$ \\
$\begin{array}{ll}\text { Shrubs and fence for safety and prevent } \\
\text { pedestrians from reckless crossings. }\end{array}$ \\
\hline Comfort & Visual aesthetics \\
\hline No trees planted. & Figures 2(a) and (b) show aligned streetlamps \\
wnpleasant to walk along during hot days. &
\end{tabular}


Only a single type of shrub planted.

The pedestrian walkway does not look

aesthetically pleasing despite the vibrant

ambience from the surrounding buildings.

The Green Zone is too small in comparison

with the building and train platform structure.

(Source: Author)

\subsubsection{Jalan Parlimen (Figures 3a;b)}
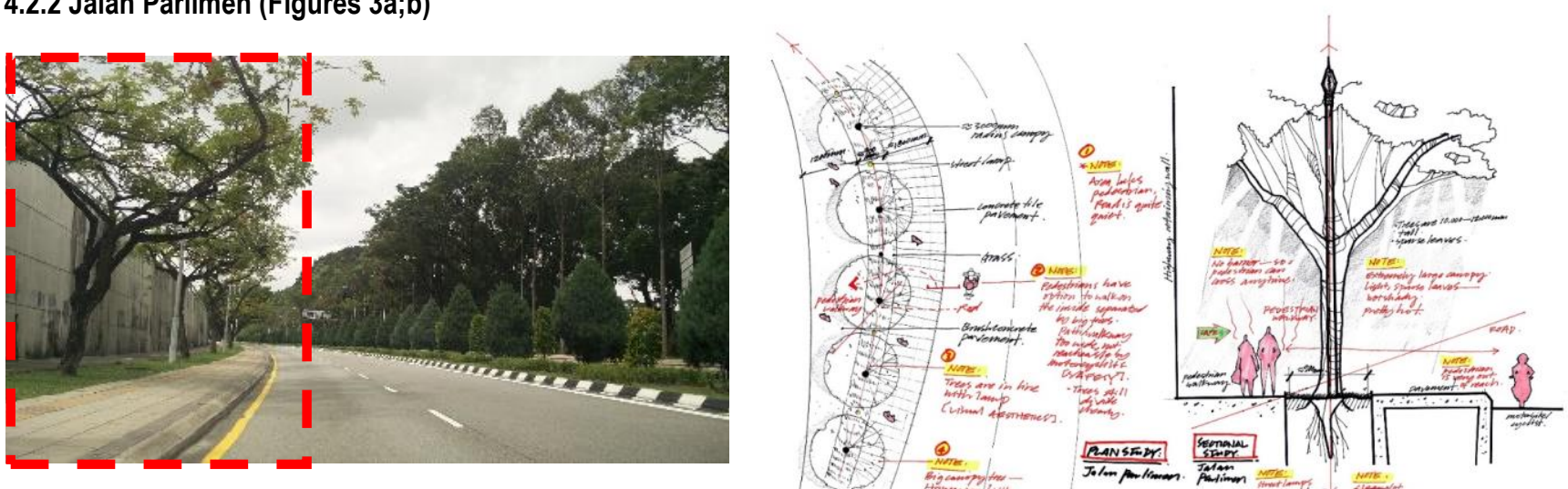

Fig. 3. (a) View of the street vegetation of Jalan Parlimen; (b) Plan and sectional studdy drawing of the street vegetation of Jalan Parlimen (Source: Author)

Table 2. Findings of the street vegetation morphology components of Jalan Parlimen.

\begin{tabular}{ll}
\hline Street location & Safety \\
\hline It is located about 50 meters from the LRT station. & Figures 3(a) and (b) show pedestrians have \\
The seamless green zone located is quiet along a & the option to walk inside a pathway of 1.8 \\
stretch of retaining wall. & meters away from the street. \\
Green zone consists of mature trees and grass. & $\begin{array}{l}\text { Even though there are no shrubs planted, the } \\
\text { grass still divides the pedestrian walkway and } \\
\text { the street, which adds contrasting texture and } \\
\text { colour of the grass to the pavement. } \\
\text { Without shrubs as a barrier, it may encourage } \\
\text { reckless crossings. }\end{array}$ \\
& \begin{tabular}{l} 
Visual aesthetics \\
\hline Comfort
\end{tabular} \\
\hline $\begin{array}{l}\text { Mature trees but the canopy are not compact with } \\
\text { leaves. }\end{array}$ & $\begin{array}{l}\text { Streetlamps aligned with trees within the } \\
\text { green zone. } \\
\text { discomfort when walking during hot days. }\end{array}$ \\
\hline
\end{tabular}

(Source: Author)

\subsubsection{Jalan Raja (Figures 4a;b)}
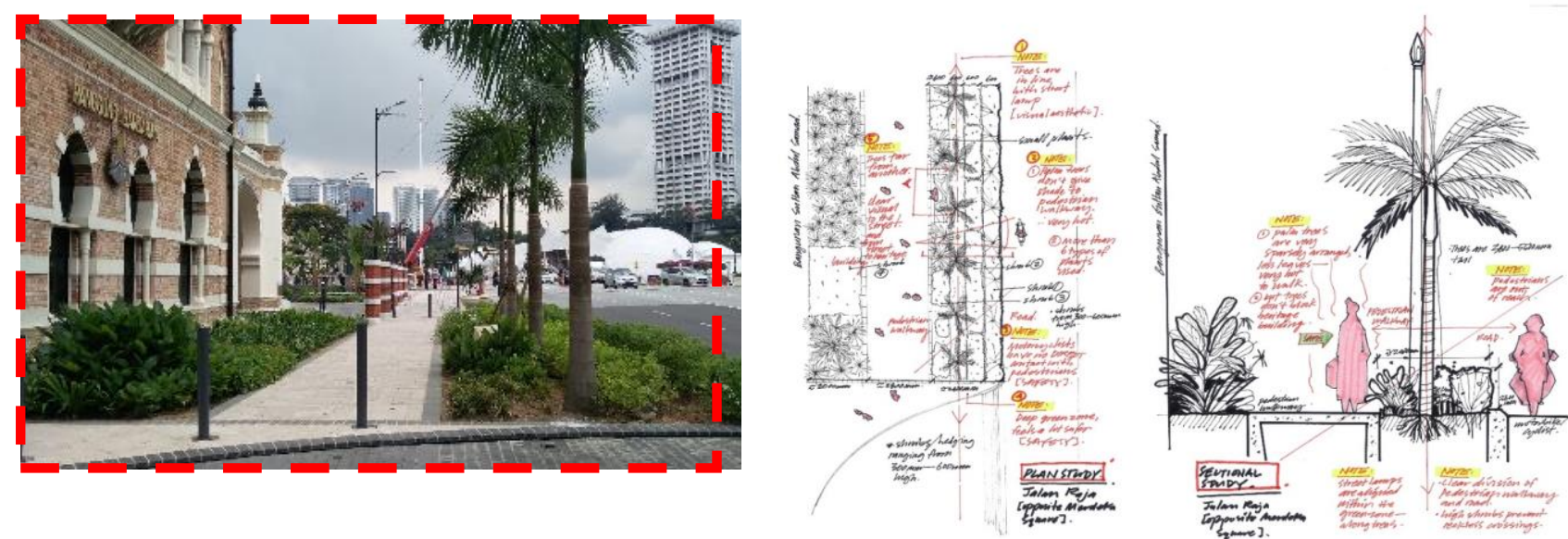

Fig.4. (a) View of the street vegetation of Jalan Raja; (b) Plan and sectional study drawing of the street vegetation of Jalan Raja (Source: Author) 
Table 3. Findings of the street vegetation morphology components of Jalan Raja.

\begin{tabular}{|c|c|}
\hline Street location & Safety \\
\hline $\begin{array}{l}\text { It is located part of heritage trail and tourists' } \\
\text { attraction (near to Merdeka Square and Sultan Abdul } \\
\text { Samad building) } \\
\text { The street is usually closed for vehicles and utilized } \\
\text { for various public events. } \\
\text { KLCH provides more budgets for maintenance along } \\
\text { this street. }\end{array}$ & $\begin{array}{l}\text { Figures } 4 a \text { ) and (b) show a clear division of } \\
\text { the pedestrian walkway and the street. } \\
\text { Shrubs help to prevent reckless crossings. }\end{array}$ \\
\hline Comfort & Visual aesthetics \\
\hline $\begin{array}{l}\text { Tall shrubs do not protect pedestrians from vehicles, } \\
\text { heat and smoke when walking along the street. } \\
\text { Quite hot and uncomfortable to walk along during } \\
\text { hot days. }\end{array}$ & $\begin{array}{l}\text { Palms provide visibility from across the street } \\
\text { towards the heritage building. } \\
\text { A variety of colours and textures of the shrubs } \\
\text { offer a beautiful walkway. }\end{array}$ \\
\hline
\end{tabular}

(Source: Author)

\subsubsection{Jalan Raja Laut (Figures 5a;b)}
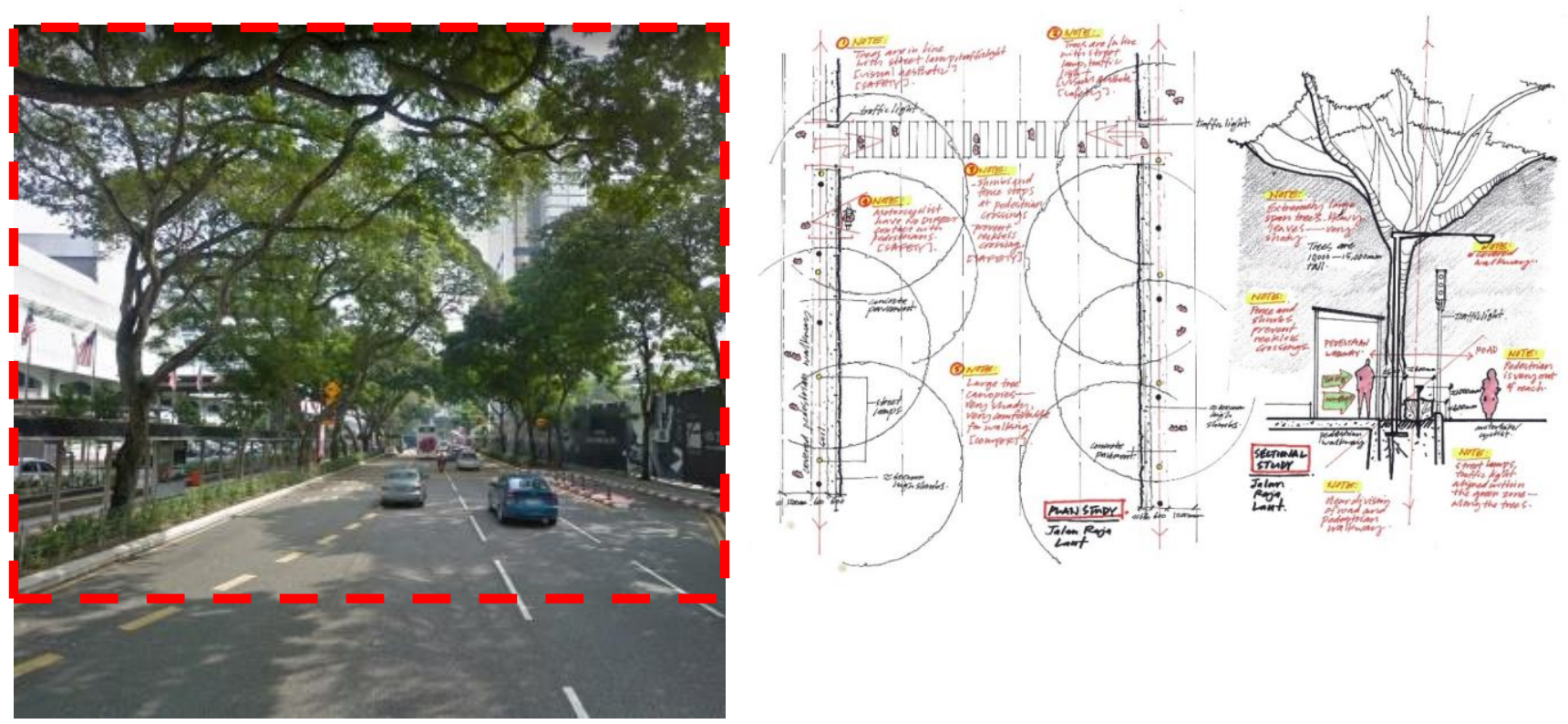

Fig.5. (a) View of the street vegetation of Jalan Raja Laut; (b) Plan and sectional study drawing of the street vegetation of Jalan Raja Laut (Source: Author)

Table 4. Findings of the street vegetation morphology components of Jalan Raja Laut.

\begin{tabular}{|c|c|}
\hline Street location & Safety \\
\hline It is located along the main street to access $\mathrm{KLCH}$. & $\begin{array}{l}\text { Figures } 5 a \text { ) and (b) show the street is planted } \\
\text { with vegetation throughout. } \\
\text { Tall shrubs with fence and large mature trees } \\
\text { give a clear boundary between the street and } \\
\text { pedestrian walkway. } \\
\text { Vegetation breaks only at pedestrian crossing } \\
\text { points for safety. }\end{array}$ \\
\hline Comfort & Visual aesthetics \\
\hline $\begin{array}{l}\text { The covered pedestrian walkway offers comfort. } \\
\text { Cool and comfortable to walk along due to large } \\
\text { trees and dense shrubs. }\end{array}$ & $\begin{array}{l}\text { Street lamps and traffic lights aligned within } \\
\text { the green zone with the trees. } \\
\text { Clean and structured layout. } \\
\text { Mature trees branch out above the street, } \\
\text { forming large canopies, and interesting } \\
\text { shadow casting makes it a beautiful path to } \\
\text { walk along. }\end{array}$ \\
\hline
\end{tabular}

(Source: Author) 


\subsubsection{Jalan Tunku Abdul Rahman (Figures 6a;b)}
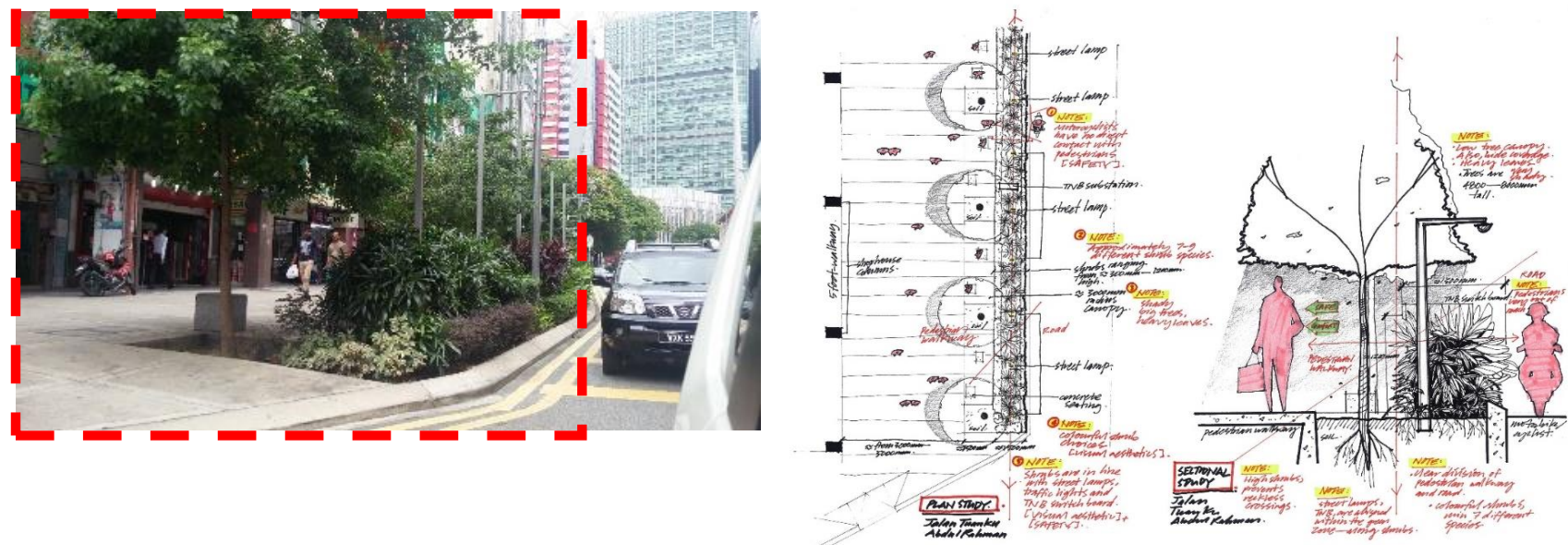

Fig.6. (a) View of the street vegetation of Jalan TAR; (b) Plan and sectional study drawing of the street vegetation of Jalan TAR (Source: Author)

Table 5. Findings of the street vegetation morphology components of Jalan Raja Laut.

\begin{tabular}{|c|c|}
\hline Street location & Safety \\
\hline $\begin{array}{l}\text { It is directly linked to Jalan Tun Perak and Jalan } \\
\text { Raja. } \\
\text { Eighty meters away from LRT station. } \\
\text { Vegetation required extensive care and maintenance } \\
\text { due to the varieties of species planted. }\end{array}$ & $\begin{array}{l}\text { Figures } 6 a) \text { and (b) show an evident division } \\
\text { between pedestrian walkway and the street. } \\
\text { Street planted with dense vegetation hence } \\
\text { very hard to cross recklessly at any point. } \\
\text { Very safe to walk along. }\end{array}$ \\
\hline Comfort & Visual aesthetics \\
\hline $\begin{array}{l}\text { Trees planted with large leaves and compact } \\
\text { canopies for shading hence offer comfort for the } \\
\text { pedestrians. } \\
\text { However, low trees with small canopies could not } \\
\text { cover the wide walkway; hence pedestrians have } \\
\text { options to walk near the shop lots. }\end{array}$ & $\begin{array}{l}\text { It is panted with a vibrant range of street } \\
\text { vegetation. } \\
\text { Streetlamps, traffic lights, and electrical } \\
\text { switchboards are constructed within the green } \\
\text { zone and inside the planting bed. These } \\
\text { hidden services made it comfortable to walk } \\
\text { along without any obstruction. }\end{array}$ \\
\hline
\end{tabular}

(Source: Author)

\subsubsection{Jalan Ampang (Figures 7a;b)}
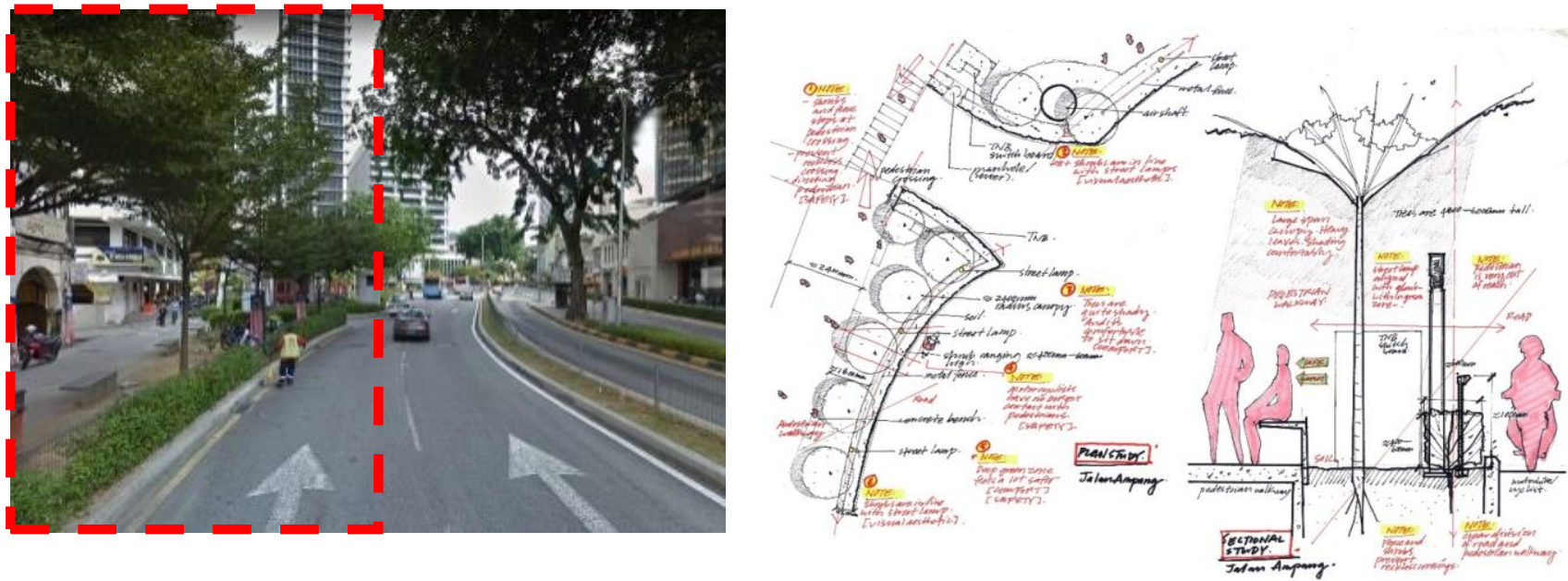

Fig.7. (a) View of the street vegetation of Jalan Ampang; (b) Plan and sectional study drawing of the street vegetation of Jalan Ampang (Source: Author) 
Table 6. Findings of the street vegetation morphology components of Jalan Ampang.

\begin{tabular}{|c|c|}
\hline Street location & Safety \\
\hline $\begin{array}{l}\text { Almost directly linked to the LRT station, which is } \\
\qquad 100 \text { meters away. }\end{array}$ & $\begin{array}{c}\text { Figures 7a) and (b) show a clear division } \\
\text { between pedestrian walkway and the street. } \\
\text { Tall shrubs and fence redefine the green } \\
\text { boundary for safety. } \\
\text { Street vegetation breaks only at pedestrian } \\
\text { crossings to prevent reckless crossings. }\end{array}$ \\
\hline Comfort & Visual aesthetics \\
\hline $\begin{array}{l}\text { Shady trees for seating areas but not wide enough } \\
\text { to shade the pedestrian walkway. }\end{array}$ & $\begin{array}{l}\text { Visually pleasing to walk along due to } \\
\text { attractive tree canopies shaped like an } \\
\text { inverted umbrella with distinctive layer } \\
\text { differentiation. } \\
\text { Electrical switchboards, ventilation shaft, and } \\
\text { streetlamps arranged in line with the green } \\
\text { zone. }\end{array}$ \\
\hline
\end{tabular}

\subsubsection{Jalan Tun H.S. Lee (Figures 8a;b)}
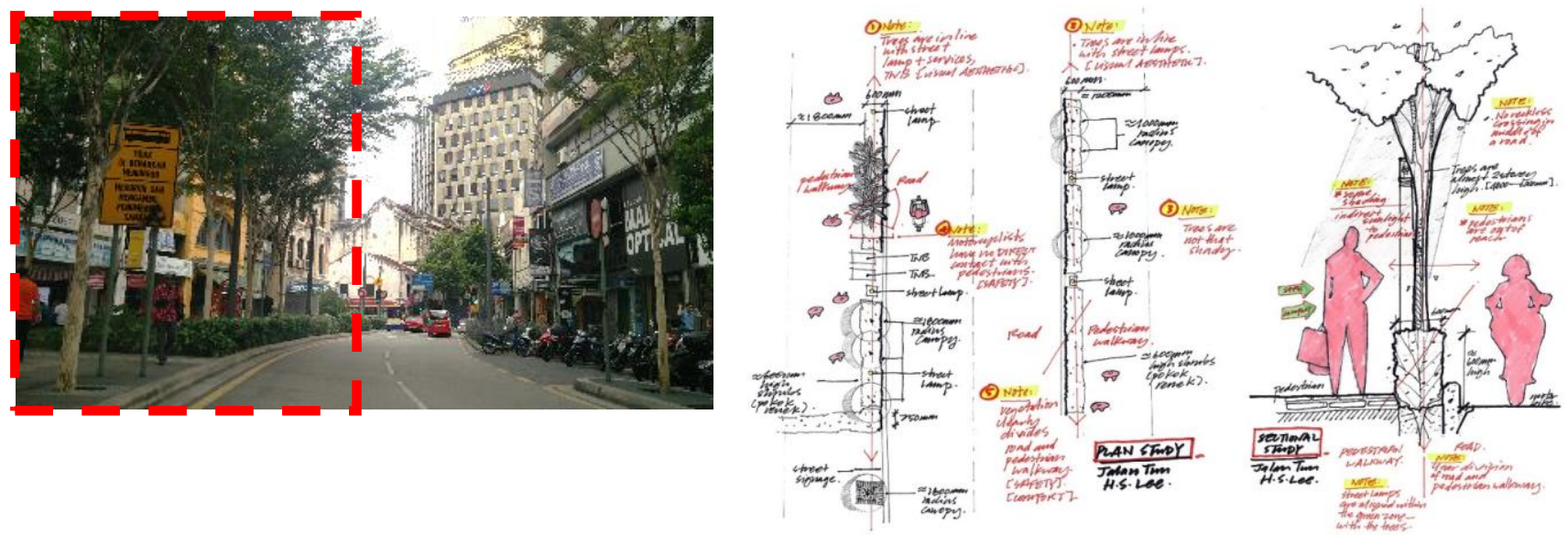

Fig.8. (a) View of the street vegetation of Jalan Tun H.S. Lee; (b) Plan and sectional study drawing of the street vegetation of Jalan Tun H.S. Lee (Source: Author)

Table 7. Findings of the street vegetation morphology components of Jalan Tun H.S. Lee

\begin{tabular}{ll}
\hline Street location & Safety \\
\hline $\begin{array}{l}\text { It is located further down, away from Jalan Raja, } \\
\text { Jalan Raja Laut, and Jalan TAR. }\end{array}$ & $\begin{array}{l}\text { Figures 8a) and (b) show a clear division } \\
\text { between pedestrian walkway and the street. } \\
\text { Shrubs act as a divider for safety. } \\
\text { Street vegetation breaks only at pedestrian } \\
\text { crossings to prevent reckless crossings. }\end{array}$ \\
& \\
\hline Comfort & Visual aesthetics \\
\hline Not much shade provided but is still comfortable to & Tree trunks have distinctive textures and \\
walk since the shop-houses are arranged solely & colours, giving an exciting character to the \\
across the vehicular lanes. & street vegetation. \\
& $\begin{array}{l}\text { Flowering shrubs for aesthetic value. } \\
\text { Streetlamps and electrical switchboards } \\
\text { arranged in line with the green zone. }\end{array}$ \\
\hline
\end{tabular}

(Source: Author) 
4.2.8 Jalan Raja Chulan (Figures 9a;b)
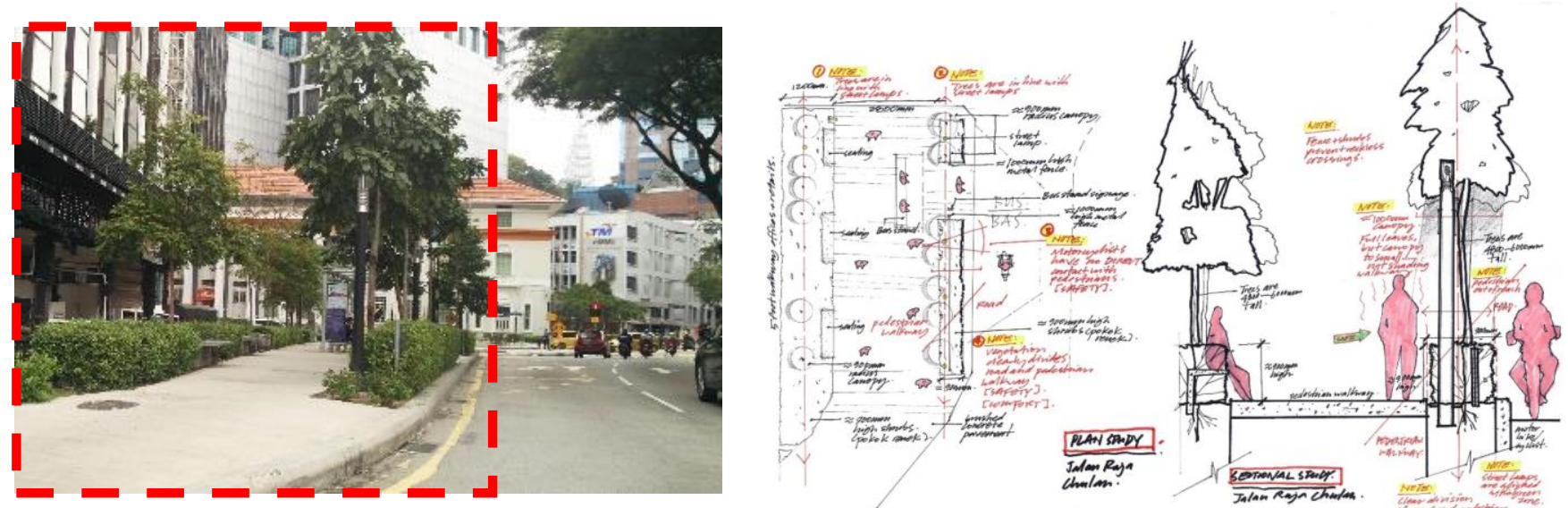

Fig.9. (a) View of the street vegetation of Jalan Raja Chulan; (b) Plan and sectional study drawing of the street vegetation of Jalan Raja Chulan (Source: Author)

Table 8. Findings of the street vegetation morphology components of Jalan Raja Chulan.

\begin{tabular}{|c|c|}
\hline Street location & Safety \\
\hline It is located the furthest from the LRT station. & $\begin{array}{l}\text { Figures } 9 \mathrm{a} \text { ) and (b) show a clear division } \\
\text { between pedestrian walkway and the street. } \\
\text { Shrubs as a divider and to prevent reckless } \\
\text { crossings. }\end{array}$ \\
\hline Comfort & Visual aesthetics \\
\hline $\begin{array}{l}\text { Not much shade provided for the pedestrian } \\
\text { walkway; hence it is scorching to walk on during the } \\
\text { hot days. } \\
\text { Seats provided for pedestrians' comfort. }\end{array}$ & $\begin{array}{l}\text { Streetlamps and electrical switchboards } \\
\text { arranged in line with the green zone. } \\
\text { Trees help to soften the structured linear } \\
\text { arrangement of the streetlamps. }\end{array}$ \\
\hline
\end{tabular}

(Source: Author)

\subsection{Discussion}

There are four main morphological components of street vegetation that construct the city hall's implementation of number six of the Entry Point Projects (EPPs) to greening Greater Kuala Lumpur.

Street Location - The composition of street vegetation is designed based on the street location. Expensive and intensive care plants are planted only along streets where the city hall has budgeted. For example, a more utilised street for special events and occasions receive more budget for labour and maintenance works.

Safety - All street vegetation works aim to increase the safety of pedestrians. The green zones along the streets act as a zone separator between pedestrians and vehicles. Since it is in the local culture that many snatch theft cases take place in the city centre, the vegetation increases the distance between the pedestrian and motorcyclists, which makes it harder to snatch. Street vegetation also acts as edges along the pedestrian walkways, preventing the pedestrians from crossing recklessly. Green zone breaks allow pedestrians to cross safely, only at specific pedestrian crossing areas.

Comfort - Street vegetation needs trees that offer canopy to the pedestrian walkways to ensure a comfortable walk. The pedestrians get shaded or at least an indirect sunlight, filtered by the tree leaves, which reduces the amount of heat reaching the walkway.

Visual Aesthetics - All utility structures are best constructed within the green zone area to ensure a tidy and structured pedestrian walkway that is pleasing to walk along hence, becomes more inviting for the pedestrians.

\subsection{Conclusion \& Recommendations}

The findings suggest that the reason for the establishment of the street vegetation to the pedestrian walkway along the main streets of Kuala Lumpur city centre is mainly responding to the safety of the pedestrians. The negative culture of snatching and reckless crossing among the locals requires street vegetation to form a clear division separating the pedestrian and street zones. Landscape works of vegetation planting help to separate the pedestrians from the vehicles on the road and keep motorcyclists out. The presence of trees also encourages people to walk (Mitchell, 2007). Therefore, more people are walking, natural surveillance is increased and prevents thefts like snatching

Street vegetation along these streets also aims to prevent pedestrians from reckless crossings as they are planted continuously along the streets. Pedestrians are forced to cross only when there are green zone breaks. From this study, it is evident that most 
landscape breaks are in the same location as the pedestrian crossings. Trees and landscaping along the streets create a friendlier environment for people to walk (Walks, 2017). Since the selected main streets in this study are linked to Jalan Tun Perak, the city hall must introduce the green zones along these streets. Data collection of pedestrian movement and distribution around the central transit hub of Kuala Lumpur would contribute to better landscape planning. The city hall shall utilise this information to plant more specific, responsive, and compelling types of trees and shrubs that would protect and comfort pedestrians.

\section{Acknowledgement}

Thank you to Landscape Architect Nik Adlin Nik Hussain, Head of Landscape Department of Kuala Lumpur City Hall and the Department of Architecture, Faculty of Built Environment, the University of Malaya for their support in this research.

\section{References}

Ayoub. (1989). The Role of City Hall In Improving The Quality Of Urban Green In Kuala Lumpur. Kuala Lumpur, Malaysia: University Of Malaya.

Burkill, I. (1966). A Dictionary Of The Economic Products Of The Malay Peninsula. Kuala Lumpur, Malaysia: Ministry of Agriculture and Cooperation.

Chevallerie, H. (1983). The Ecology and Preservation of Street Trees. In D. G. A.D. Bradshaw, Ecology and Design in Landscape, 24th Symposium of the British Ecological Society (pp. 345-355). Oxford: Blackwell Scientific Publication.

Chiesura, A. (2004). The Role Of Urban Parks For The Sustainable City. Landscape and Urban Planning, 129-138. DBKL. (2004, August 12). Urban Design and Landscape. Retrieved from Kuala Lumpur Structure Plan 2020: http://www.dbkl.gov.my/pskl2020/english/urban_design_and_landscape/index.htm

Dimoudi, M. (2003). Vegetation In The Urban Environment: Microclimatic Analysis And Benefits. Energy and Building 35, 69-76.

Foundation, H. (2003, March). Heart Foundation. Retrieved from file:///C:/Users/AMEELIA/Downloads/TreesLandscapingSnapshot_proof5.pdf

Government, M. o. (2010, July 26). Program Bandar Selamat 2010. Retrieved from Portal 1Klik: http://pmr.penerangan.gov.my/index.php/keselamatan/7148-programbandar-selamat-2010.html

Jacobs, A. (1993). Great Street. Massachusetts: M.I.T.

Juriah Zakaria, N. U. (2015). Comfort of Walking in the City Center of Kuala Lumpur. Social And Behavioral Sciences 170, 642-652.

Kent, R. (1993). Attributes, Features and Reasons For Enjoyment of Scenic Routes: A Comparison of Experts, Residents And Citizens. Landscape Research 18, 92102.

Koening, J. (1894). Journal of a voyage from India to Siam and Malacca in 1779. Journal of the Straits Branch of the Royal Asiatic Society $26,58-201$.

L.M. Anderson, H. C. (1988). Influence Of Trees On Residential Property Values in Athens, Georgia (USA): A Survey Based On Actual Sales Prices. Landscape Urban Planning 15, 153-164.

M. Sreetheran, M. A. (2011). Street Tree Inventory and Tree Risk Assessment of Selected Major Roads in Kuala Lumpur, Malaysia. Scientific Journal of the International Society of Agriculture, 226-235.

Miller, B. (2014). Mesopotamia to Milwaukee: A Brief History of Trees In The City. Retrieved from www.isa-arbor.com: http://www.isaarbor.com/events/conference/proceedings/2014/2014_Bob_Miller.pdf

Niti B. Mishra, K. A. (2015). Mapping Vegetation Morphology Types in Southern Africa Savanna Using MODIS Time-Series Metrics: A Case Study of Central Kalahari, Botswana. Land, 194-215.

Oxford. (2012). Oxford English Dictionary. Oxford: Oxford University Press.

Pradines, C. (2009). Road Infrastructures: Tree Avenues In The Landscape. Strasbourg: Council of Europe.

R Mitchell, F. P. (2007). Greenspace, Urbanity And Health: Relationships In England. Epidem and Community Health, 681.

Shuhana Shamsuddin, N. R. (2012). Walkable Environment In Increasing The Liveability Of A City. Procedia Social and Behavioral Sciences 50, $167-178$.

Smardon, R. (1988). Perception and Aesthetics Of The Urban Environment: Review Of The Role Of Vegetation. Landscape Urban Planning 15, 85-106.

Technology, E. S. (2012, August 29). Green Plants Reduce Pollutions On City Streets Up to Eight Times More Than Previously Believed. Retrieved from ACS: https://www.acs.org/content/acs/en/pressroom/presspacs/2012/acs-presspac-august-29-2012/green-plants-reduce-pollution-on-city-streets-up-to-eight-times-more-thanpreviously-believed.html

Walks, V. (2017, May). Street Trees And Planting. Retrieved from Victoria Walks: http://www.victoriawalks.org.au/trees/ 